\title{
Potensi Tepung Umbi Dahlia Dan Ekstrak Inulin Dahlia Sebagai Sumber Karbon Dalam Produksi Fruktooligosakarida (FOS) Oleh Khamir Kluyveromyces marxianus DUCC-Y-003
}

\author{
Rida Yuliana ${ }^{1}$, Endang Kusdiyantini ${ }^{2}$, dan Munifatul Izzati $^{3}$ \\ Mahasiswa Magister Biologi Universitas Diponegoro \\ Dosen Jurusan Biologi FSM Universitas Diponegoro
}

\begin{abstract}
Abstrak
Penelitian ini bertujuan untuk mengeksplorasi manfaat umbi dahlia dalam bentuk tepung umbi dan ekstrak inulin sebagai substrat untuk memproduksi FOS. Produksi FOS berlangsung secara mikrobial enzimatis dengan bantuan khamir Kluyveromyces marxianus DUCC-Y-003. Pengkulturan khamir pada media kultur berlangsung selama 60 jam dan dilakukan pengukuran tiap 6 jam. Pengukuran tersebut meliputi pertumbuhan khamir, kadar fruktosa medium dan kadar total gula medium. Penentuan FOS dilakukan dengan cara mengukur nilai derajat polimerisasi (DP). DP merupakan hasil perbandingan antara kadar total gula dengan kadar fruktosa pada media kultur. DP FOS berkisar antara 2-10 dan FOS komersil dengan DP 3-5. Penelitian menggunakan Rancangan Acak Kelompok Faktorial (RAKF). Perlakuan terdiri atas S1D1 (substrat tepung, dosis $1 \mathrm{~g}$ ), S1D2 (tepung, 3 g), S1D3 (tepung, $5 \mathrm{~g}$ ), S2D1 (ekstrak inulin, $1 \mathrm{~g}$ ), S2D2 (ekstrak inulin, $3 \mathrm{~g}$ ), S2D3 (ekstrak inulin, $5 \mathrm{~g}$ ). Hasil penelitian menunjukkan bahwa pertumbuhan khamir tertinggi pada perlakuan penggunaan ekstrak inulin dengan dosis 1 gram, dan pertumbuhan terendah pada perlakuan penggunaan tepung dengan dosis 5 gram. Pada masing-masing perlakuan, menghasilkan produk FOS dengan nilai DP yang beragam selama waktu inkubasi 60 jam, hanya perlakuan S2D1 (ekstrak inulin, 1g) yang sudah menghasilkan ketiga jenis FOS komersil dalam waktu inkubasi 60 jam. Pada perlakuan S2D1, produk 1-kestosa dihasilkan saat inkubasi 42 jam, produk nystosa saat 48 jam dan produk fruktofurasylnystosa saat 60 jam. Kesimpulan hasil penelitian adalah perlakuan S2D1 paling efektif dalam menghasilkan FOS selama waktu inkubasi 60 jam, sedangkan perlakuan lain dapat menghasilkan FOS yang sama jika lama waktu inkubasi diperpanjang.
\end{abstract}

Kata kunci : inulin, inulinase, derajat polimerisasi, Kluyveromyces marxianus DUCC-Y-0003

\section{PENDAHULUAN}

Fruktooligosakarida (FOS) adalah oligosakarida yang tersusun atas 2-10 unit monomer fruktosa dengan ikatan $\beta-(2-1)$ glikosidik dan satu monomer glukosa dengan ikatan $\alpha$-(2-1) glikosidik pada ujungnya (Rossi et al., 2005). FOS merupakan bahan aditif yang sering dimanfaatkan untuk industri pangan, farmasi dan kimia. FOS bernilai fungsional, karena memiliki manfaat : sebagai prebiotik, serat larut (soluble dietary fiber), faktor stimulat Bifidus, pemanis rendah kalori, bersifat non-karsinogenik, dan berfungsi baik untuk manajemen kesehatan saluran cerna (management gut health) (Pool_Zobel, 2005).

FOS secara luas sudah diaplikasikan dalam beberapa industri makanan dan farmasi. Ketersediaan FOS untuk industri dalam negeri sebagian besar masih impor. Produksi FOS di
Indonesia belum berkembang dengan baik, karena : belum adanya produsen FOS, bahan dasar untuk produksi FOS belum banyak dikenal, inovasi teknologi produksi FOS masih bersifat eksploratif, dan FOS belum diasosiasikan dengan baik kepada masyarakat (Mangunwidjaja, 2009; Wijanarka, 2011).

FOS dapat diproduksi dari senyawa inulin secara enzimatis dengan bantuan mikroorganisme. Inulin adalah suatu polifruktan yang tersusun atas molekul linear D-fruktofuranosa dengan ikatan $\beta$ 2-1-glikosidik dan memiliki gugus terminal Dglukosa yang berikatan dengan fruktosa melalui ikatan $\alpha$-1-2-glikosidik. Inulin terbentuk sebagai karbohidrat cadangan pada umbi akar beberapa tanaman Compositae, seperti jerusalem artichoke, chicory, dan dahlia. (Gupta et al, 1992). Ketiga tanaman diatas memiliki kandungan inulin yang tinggi, sehingga sering dimanfaatkan sebagai 
sumber penghasil inulin secara komersial. Akan tetapi, hanya tanaman dahlia yang dapat cocok dikembangkan di Indonesia (Manguwidjaja, 2009).

Di Indonesia, dahlia dimanfaatkan sebagai tanaman bunga potong. Potensi tanaman dahlia dapat dieksplorasi tingkat lanjut pada umbi akarnya. Umbi dahlia mengandung karbohidrat inulin yang bernilai komersil dan memiliki nilai fungsional sebagai bahan makanan. Umbi dahlia segar mengandung inulin dengan kadar 72,6\% (bk), sedangkan setelah proses ekstraksi lanjutan diperoleh inulin murni sekitar 41,7\% (bk) dari total inulin yang terkandung pada umbi (Widowati dkk., 2005).

Penelitian ini memanfaatkan umbi dahlia sebagai sumber inulin dengan dua proses pengolahan, yaitu pembuatan tepung umbi dan ekstraksi inulin dengan etanol. Tepung umbi dahlia merupakan konversi langsung dari umbi dahlia dengan penghilangan komponen air, sedangkan ekstrak inulin umbi dahlia yaitu hasil dari proses pemisahan senyawa inulin dari komponen lain yang terdapat pada umbi dahlia (Widowati, 2005). Kedua bentuk bahan tersebut, masing-masing akan diuji tingkat selektifitasnya sebagai sumber karbon pada media pengkulturan mikroorganisme uji dalam menghasilkan FOS. Substrat yang selektif dapat menginduksi lebih baik suatu sel dalam mensintesis enzim inulinase, sehingga dapat menghasilkan produk yang diinginkan (Rouwenhorst, et al., 1988; Rukmana, 2000).

Beberapa mikroorganisme diketahui memiliki aktivitas inulinase, misalnya jenis khamir Kluyveromyces marxianus DUCC-Y-003. Genus Kluyveromyces diketahui memiliki aktivitas inulinase yang tinggi dalam mendegradasi substrat inulin (Singh, 2006). Kelimpahan khamir Kluyveromyces marxianus dapat diekplorasi dari rhizosfer umbi dahlia (Saryono dkk., 2002). Khamir yang digunakan dalam penelitian, diisolasi langsung dari rhizosfer umbi dahlia yang diperoleh dari daerah Bandungan, Ungaran.

Hasil penelitian ini dapat menjadi prospek ke depan untuk membangun kemandirian di bidang pangan. Teknologi biokonversi dari bahan baku umbi dahlia ini memiliki perspektif yang baik dalam rangka meningkatkan nilai guna umbi dahlia sebagai salah satu sumber alternatif pangan fungsional seperti FOS.

\section{BAHAN DAN METODE}

1. Pengolahan Umbi Dahlia

a. Pengolahan Umbi Dahlia dalam Bentuk Tepung

Umbi dahlia dibersihkan dari kotoran, dicuci dengan air mengalir, kemudian dikupas, dan diiris tipis-tipis. Irisan tersebut dijemur di bawah sinar matahari langsung dan dikeringanginkan, atau dikeringkan dalam oven suhu $80^{\circ} \mathrm{C}$. Irisan umbi yang sudah kering dihaluskan dengan chopper atau digiling hingga hancur dan disaring dengan ayakan 60 mess, sehingga dihasilkan serbuk halus atau tepung (Widowati, 2009).

b. Pengolahan Umbi Dahlia dalam Menghasilkan Ekstrak Inulin

Umbi dahlia dibersihkan dari kotoran, dicuci dengan air mengalir, kemudian dikupas, dipotong kecil-kecil dan diblender dengan penambahan air 1:2 (b:v). Selanjutnya, dipanaskan pada penangas air dengan suhu $80-90^{\circ} \mathrm{C}$ selama \pm 30 menit. Setelah dingin, disaring dan diambil filtratnya. Filtrat dilarutkan dalam etanol 30\% sebanyak $40 \%$ dari volume filtrat. Larutan disimpan pada suhu $0^{\circ} \mathrm{C}$ selama \pm 18 jam. Larutan dibiarkan pada suhu ruang selama 2 jam atau didiamkan hingga terdapat endapan. Endapan yang diperoleh merupakan inulin basah I yang selanjutnya dilarutkan kembali dengan air dengan volume 1:2 (b:v). Proses lanjut sama seperti diatas hingga diperoleh endapan inulin basah II. Tahap akhir, inulin basah II dikeringkan pada suhu $50-60^{\circ} \mathrm{C}$ selama 6-7 jam dan dihaluskan hingga menjadi serbuk inulin (Widowati dkk., 2005).

2. Pembuatan Media Kultur Khamir Kluyveromyces marxianus DUCC-Y-003

a. Media Kultur Starter

Ekstrak inulin dari umbi dahlia sebanyak 1 gram dilarutkan dalam $100 \mathrm{~mL}$ akuades, dipanaskan pada suhu $50^{\circ} \mathrm{C}$ selama 10 menit atau hingga larut. Selanjutnya, ditambahkan $0,5 \quad \mathrm{~g} \quad\left(\mathrm{NH}_{4}\right)_{2} \mathrm{SO}_{4} ; \quad 0,05 \mathrm{~g}$ $\mathrm{MgSO}_{4} 7 \mathrm{H}_{2} \mathrm{O} ; \quad 0,3 \quad \mathrm{~g} \quad \mathrm{KH}_{2} \mathrm{PO}_{4} ; \quad 0,01 \quad \mathrm{~g}$ $\mathrm{CaCl}_{2} \cdot 2 \mathrm{H}_{2} \mathrm{O} ; 0,4 \mathrm{~g} \mathrm{Na}_{2} \mathrm{HPO}_{4} ; 0,2 \mathrm{~g}$ ekstrak 
yeast dan $0,5 \mathrm{~g}$ pepton pada $\mathrm{pH} 6$ (Pessoa \& Vitolo, 1999). Sterilisasi dengan autoklaf pada suhu $121^{\circ} \mathrm{C}$, tekanan 2 atm selama 15 menit.

b. Media Kultur Perlakuan

Variasi jenis dan dosis sumber karbon menjadi faktor perlakuan pada penelitian ini. Adapun jenis sumber karbon untuk perlakuan, yaitu tepung umbi dahlia dan ekstrak inulin umbi dahlia dengan dosis masing-masing $1 \mathrm{~g}$, $3 \mathrm{~g}$ dan $5 \mathrm{~g}$. Tepung dan ekstrak inulin umbi dahlia masing-masing dilarutkan dalam 100 $\mathrm{mL}$ akuades, dipanaskan selama 25 menit dan disaring. Filtrat yang dihasilkan ditambahkan komponen mineral yang sama seperti di atas. Jika volume filtrat berkurang, maka dilakukan penambahan akuades hingga volume menjadi $100 \mathrm{~mL}$. Kemudian, dilanjutkan dengan pengecekan $\mathrm{pH} 6$ dan sterilisasi pada suhu $121^{\circ} \mathrm{C}$, tekanan 2 atm selama 15 menit.

3. Pembuatan Starter

Satu ose isolat khamir Kluyveromyces marxianus DUCC-Y-003 diinokulasikan ke dalam $50 \mathrm{~mL}$ media kultur starter, dan diinkubasi dengan agitasi $150 \mathrm{rpm}$ pada suhu ruang selama 20 jam untuk aktivasi awal (prestarter) dengan kepadatan kultur $1,8 \times 10^{7}$ $\mathrm{sel} / \mathrm{mL}$. Selanjutnya, kultur prestarter di aktivasi kembali ke dalam $100 \mathrm{~mL}$ media kultur starter selama 15 jam (kepadatan kultur $2,5 \times 10^{7} \mathrm{sel} / \mathrm{mL}$ ), dan digunakan sebagai starter dalam produksi fruktooligosakarida (FOS) pada tahap lanjut.

4. Pengkulturan Khamir Kluyveromyces marxianus DUCC-Y-003 pada Media Perlakuan

Kultur starter sebanyak $10 \% \quad(\mathrm{v} / \mathrm{v})$ diinokulasikan dalam $100 \mathrm{~mL}$ media perlakuan, dan diinkubasi dengan agitasi 150 rpm pada suhu ruang selama 60 jam. Pengambilan kultur sampel sebanyak $5 \mathrm{~mL}$ dilakukan setiap 6 jam untuk mengukur pertumbuhan sel secara langsung dengan metode turbidimetri menggunakan spektrofotometer pada $\lambda 520 \mathrm{~nm}$. Nilai kerapatan optis (OD) yang dihasilkan dapat memperlihatkan pola pertumbuhan khamir selama masa inkubasi, serta dapat disinkronkan dengan produk fruktooligosakarida yang dihasilkan.

5. Penentuan Produk Fruktooligosakarida (FOS) Produk FOS terbentuk dari aktivitas enzimatis khamir Kluyveromyces marxianus DUCC-Y003 pada media perlakuan. Keberadaan FOS dalam media perlakuan dapat diketahui melalui pengukuran derajat polimerisasi (DP). Nilai DP ditentukan dari perbandingan kadar total gula dan fruktosa dalam media, dengan rumusan :

Derajat Polimerisasi (DP) $=\frac{\text { Kadar Total Guls }}{\text { Kadrr Fruktosa }}$

DP FOS berkisar 2-10, nilai tersebut menunjukkan jumlah unit monomer fruktosa penyusun FOS, sebab FOS merupakan suatu oligomer yang tersusun atas 2-10 unit monomer penyusunnya (Yun et al, 1999).

a. Pengukuran Kadar Fruktosa

Kultur sampel disentrifugasi dengan kecepatan $3000 \mathrm{rpm}$ selama 20 menit pada suhu ruang. Supernatan hasil sentrifugasi diambil sebanyak $1 \mathrm{~mL}$ dan direaksikan dengan reagen DNS sebanyak $1 \mathrm{~mL}$. Larutan tersebut dididihkan selama 10 menit hingga terjadi perubahan warna. Larutan diencerkan dengan $5 \mathrm{~mL}$ akuades dan diukur kerapatan optisnya menggunakan spektrofotometer pada $\lambda 570 \mathrm{~nm}$ (Chaplin dan Kennedy, 1994). Kadar fruktosa ditentukan dengan rumusan :

$\operatorname{Kadar}$ Fruktosa $(\mathrm{mg} / \mathrm{mL})=\frac{(\text { Nilai ab sorbansi) }+ \text { U,U288 }}{0,5398}$

b. Pengukuran Kadar Total Gula

Sisa supernatan hasil tahap pengukuran fruktosa, diambil sebanyak $0,2 \mathrm{~mL}$ direaksikan dengan $0,2 \mathrm{~mL}$ fenol $5 \%$ dalam tabung reaksi, kemudian ditambah dengan 1 $\mathrm{mL} \mathrm{H}_{2} \mathrm{SO}_{4}$ pekat secara cepat, dan langsung tertuju pada permukaan campuran supernatan-fenol tanpa bersentuhan dengan sisi tabung. Larutan didiamkan selama 10 menit, selanjutnya digojog secara cepat dengan homogenisator. Larutan diencerkan dengan $5 \mathrm{~mL}$ akuades dan digojog kembali. 
Selanjutnya, dididihkan selama 15 menit dan diukur kerapatan optisnya pada $\lambda 480 \mathrm{~nm}$ dilakukan setelah larutan dingin (Chaplin dan Kennedy, 1994). Kadar total gula ditentukan dengan rumus :

Kadar Total Gula $(\mu \mathrm{g} / \mathrm{mL})=\frac{(\text { Nilai ab5orbansi })+2,1218}{0,0003698}$

\section{Parameter Penelitian}

- Pertumbuhan khamir Kluyveromyces marxianus DUCC-Y-003 pada media perlakuan.

- Produk fruktooligosakarida (FOS) yang terbentuk pada media perlakuan yang terukur dari besarnya nilai derajat polimerisasi.

\section{Rancangan Percobaan}

Penelitian dilaksanakan secara

eksperimental menggunakan Rancangan Acak

Kelompok Faktorial (RAKF) dengan 3 kelompok ulangan. Adapun faktor perlakuan yaitu jenis sumber karbon (notasi $=\mathrm{S}$ ) dan dosis (notasi $=\mathrm{D})$.

S1 : tepung umbi dahlia

S2 : ekstrak inulin dari umbi dahlia

D1 : dosis 1 gram

$\mathrm{D} 2$ : dosis 3 gram

D3 : dosis 5 gram

Kombinasi perlakuan sebagai berikut :

\begin{tabular}{c|ccc}
\hline Perlakuan & D1 & D2 & D3 \\
S1 & S1D1 & S1D2 & S1D3 \\
S2 & S2D1 & S2D2 & S2D3 \\
\hline
\end{tabular}

Data hasil penelitian yang dianalisis statistik adalah nilai derajat polimerisasi FOS dari berbagai perlakuan. Analisis data menggunakan metode analisis sidik ragam (ansira) dan dilanjutkan dengan uji BNT (Beda Nyata Terkecil) pada taraf signifikan 5\% ( $<$ 0,05) (Hanafiah, 1993).

\section{HASIL DAN PEMBAHASAN}

Tepung umbi dan ekstrak inulin dari umbi dahlia mampu berperan sebagai substrat pertumbuhan khamir Kluyveromyces marxianus DUCC-Y-003. Khamir ini dapat mendegradasi kedua substrat, karena mampu mensintesis enzim inulinase. Sintesis enzim inulinase terjadi karena adanya induksi dari substrat yang selektif, yaitu inulin. Interaksi antara enzim inulinase dan substrat inulin akan membentuk kompleks enzim substrat (ES). Selanjutnya, adanya kompleks ES maka dapat terbentuk suatu produk $(\mathrm{P})$, misalnya fruktooligosakarida (FOS).

Hasil penelitian ini, menunjukkan bahwa penggunaan substrat tepung dan ekstrak inulin dari umbi dahlia dapat menghasilkan produk FOS dari hasil aktivitas enzimatis khamir Kluyveromyces marxianus DUCC-Y-003. FOS yang dihasilkan terdapat dalam cairan media kultur. Keberadaan FOS merupakan hasil dari pertumbuhan dan aktivitas degradatif khamir terhadap substrat. Oleh karena itu, untuk mengetahui efektifitas kedua jenis substrat tersebut, maka dilakukan pengamatan terhadap perbedaan pertumbuhan khamir dan produk FOS yang dihasilkan pada cairan media tumbuh khamir.

\section{Perbedaan Pertumbuhan Khamir} Kluyveromyces marxianus DUCC-Y-003 pada Media Tepung dan Ekstrak Inulin dari Umbi Dahlia

Pengukuran pertumbuhan khamir Kluyveromyces marxianus DUCC-Y-003 pada media tumbuh merupakan salah satu aspek yang diamati dalam penelitian. Hal ini berkaitan dengan aktivitas degradatif khamir terhadap substrat untuk tumbuh dan berkembang, sehingga membentuk produk seperti FOS. Pertumbuhan pada suatu mikroorganisme adalah penambahan secara teratur semua komponen sel suatu mikroorganisme. Pertumbuhan dapat diamati dari meningkatnya jumlah sel atau massa sel (Fardiaz, 1992). Pertambahan massa sel khamir terjadi karena khamir memperoleh nutrisi dari media kultur dan mampu memanfaatkannya untuk tumbuh dan berkembang.

Pertumbuhan dapat diukur secara tidak langsung dengan mengukur turbiditas cairan media tumbuh. Metode ini digunakan untuk menaksir (memperkirakan) berat atau jumlah biomassa total dalam suspensi kultur. Turbiditas dapat diukur menggunakan alat spektrofotometer. Prinsip kerja alat ini adalah pengukuran kerapatan atau densitas populasi mikroorganisme dalam media tumbuh melalui banyak sedikitnya cahaya yang diserap atau diteruskan (kerapatan optis / OD). Semakin 
pekat atau semakin banyak populasi mikroorganisme, maka cahaya yang diserap semakin banyak dan yang diteruskan semakin sedikit. Pertumbuhan mikroorganisme pada media tumbuh akan ditunjukkan dengan bertambahnya nilai kerapatan optis dengan bertambah lamanya waktu inkubasi pada media (Poedjiadi, 2006).

Hasil pengamatan pertumbuhan khamir Kluyveromyces marxianus DUCC-Y-003 pada media tepung umbi dahlia dan ekstrak inulin dengan berbagai dosis ( $1 \mathrm{~g}, 3 \mathrm{~g}, 5 \mathrm{~g}$ ) terdapat pada Gambar 4.1. Penggunaan tepung umbi dahlia dan ekstrak inulin dalam media kultur berperan sebagai sumber karbon bagi pertumbuhan khamir. Karbon merupakan elemen makronutrien utama yang berperan penting bagi sistem metabolisme khususnya sebagai kerangka makromolekul seluler dari khamir (Waluyo, 2004).

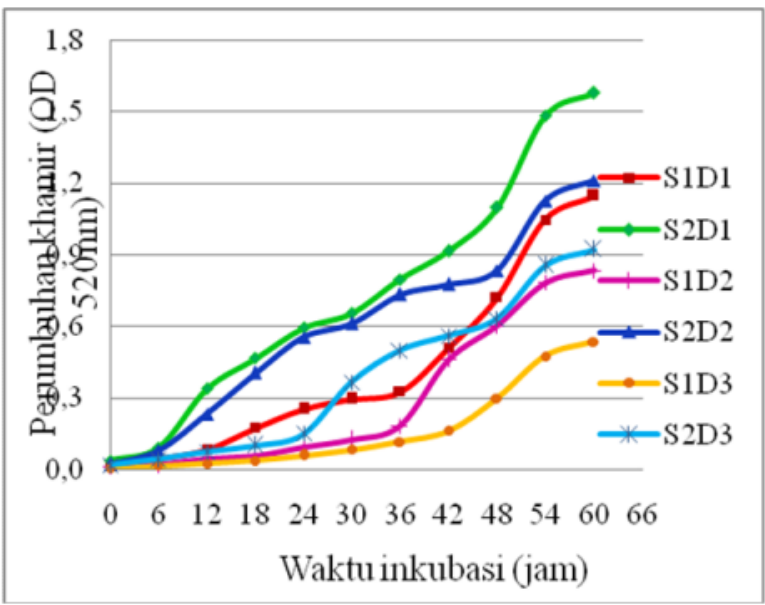

Gambar 1. Kurva pertumbuhan K. marxianus DUCCY-003 pada media perlakuan $(\mathrm{S} 1 \mathrm{D} 1=$ Tepung $1 \mathrm{~g}, \mathrm{~S} 1 \mathrm{D} 2=$ Tepung $3 \mathrm{~g}, \mathrm{~S} 1 \mathrm{D} 3=$ Tepung $5 \mathrm{~g}, \mathrm{~S} 2 \mathrm{D} 1=$ Ekstrak $1 \mathrm{~g}, \mathrm{~S} 2 \mathrm{D} 2=$ Eksrak 3 g, S2D3 = Ekstrak 5 g).

Berdasarkan gambar kurva pertumbuhan di atas, semua perlakuan menunjukkan kecenderungan pola pertumbuhan khamir yang sama. Kurva pertumbuhan tersebut memperlihatkan pola pertumbuhan sel khamir pada kurun waktu inkubasi 60 jam. Pola pertumbuhan tertinggi terlihat pada perlakuan ekstrak inulin $1 \mathrm{~g}$ (S2D1) dan yang terendah terlihat pada perlakuan tepung umbi dahlia $5 \mathrm{~g}$ (S1D3).

Pertumbuhan sel khamir Kluyveromyces marxianus DUCC-Y-003 tertinggi terjadi pada medium yang bersumber karbon ekstrak inulin sebanyak $1 \mathrm{~g} / 100 \mathrm{~mL}$ medium. Adapun peningkatan dosis hingga $3 \mathrm{~g}$ dan $5 \mathrm{~g}$, menunjukkan pertumbuhan sel yang semakin lambat. Artinya, semakin tinggi dosis ekstrak inulin, menyebabkan peningkatan viskositas sehingga sel khamir membutuhkan waktu lebih lama untuk mensintesis enzim yang berperan dalam katabolisme inulin.

Kondisi serupa tampak pada perlakuan tepung umbi dahlia yang ditunjukkan dengan pertumbuhan tertinggi sel khamir pada dosis $1 \mathrm{~g}$. Penambahan dosis hingga $3 \mathrm{~g}$ dan $5 \mathrm{~g}$ juga menyebabkan pertumbuhan sel khamir menjadi lambat. Hal ini disebabkan sel khamir mengalami tingkat kejenuhan dalam mendegradasi substrat yang terlalu pekat.

Aktivitas khamir dalam menghidrolisis media perlakuan merupakan salah satu bentuk aktivitas enzimatik dalam memecah inulin menjadi fruktooligosakarida (FOS). Peningkatan dosis substrat inulin dapat meningkatkan laju reaksi enzim inulinase, namun penambahan tingkat lanjut dapat menyebabkan penurunan laju reaksi pada enzim inulinase karena enzim jenuh dengan substrat (Page, 1989). Kondisi enzim menjadi jenuh dengan substrat berarti sisi aktif enzim yang semula sangat sensitif terhadap substrat yang kompatibel, pada akhirnya menjadi reaktif karena terjadi penurunan fungsi. Besar dosis substrat berhubungan dengan kompleks enzim substrat yang terbentuk dan berpengaruh terhadap kecepatan reaksi enzim (Lehninger, 1982).

Perbandingan pertumbuhan khamir Kluyveromyces marxianus DUCC-Y-003 antara media tepung umbi dan ekstrak inulin, menunjukkan hasil lebih baik pada media ekstrak inulin. Khamir lebih mudah mendegradasi ekstrak inulin, alasannya komponen senyawa inulin yang terkandung di dalamnya lebih murni karena sudah melalui proses ekstraksi bertingkat dengan menggunakan pelarut etanol (Widowati, 2005). Berbeda dengan tepung umbi dahlia menghasilkan pertumbuhan lebih lambat karena khamir membutuhkan waktu lebih lama untuk mensintesis 
enzim inulinase. Inulinase bekerja selektif dengan adanya substrat inulin. Pada tepung umbi dahlia, belum dilakukan separasi (pemisahan) tingkat lanjut senyawa inulin dari campuran senyawa lain yang terkandung dalam umbi dahlia.

Pertumbuhan khamir Kluyveromyces marxianus DUCC-Y-003 pada media perlakuan merupakan hasil dari aktivitas khamir dalam mensintesis enzim inulinase. Enzim inulinase termasuk enzim induktif atau adaptif yang disintesis ketika terinduksi substrat inulin (Poedjiadi, 2006). Hal ini dibuktikan melalui kurva pertumbuhan 4.1. yang menunjukkan bahwa pertumbuhan khamir Kluyveromyces marxianus DUCC-Y-003 pada ekstrak inulin lebih tinggi daripada tepung. Adanya selektifitas media dengan sumber karbon ekstrak inulin menyebabkan peningkatan sintesis enzim inulinase pada khamir. Berbeda pada tepung umbi dahlia masih terkandung material lain yang dapat menghambat pertumbuhan khamir. Keberadaan material selain inulin menyebabkan penurunan efektifitas khamir dalam mensintesis enzim inulinase, sehingga berpengaruh pada penurunan pertumbuhan khamir (Saryono, 2008).

Penggunaan tepung umbi dahlia untuk memproduksi FOS kurang efektif dari segi waktu produksi. Akan tetapi, dalam rangka memperoleh manfaat inulin dari umbi dahlia, prosedur pembuatan tepung umbi jauh lebih sederhana dan terjangkau dibanding proses ekstraksi bertingkat. Berdasarkan gambar 4.1., tepung umbi juga mampu dimanfaatkan khamir Kluyveromyces marxianus DUCC-Y-003 untuk mendukung pertumbuhannya. Oleh karena itu, penggunaan tepung umbi dahlia dapat menjadi alternatif untuk proses produksi FOS yang lebih sederhana.

2. Perbedaan Produksi Fruktooligosakarida (FOS) oleh Khamir Kluyveromyces marxianus DUCC-Y003 pada Media Tepung dan Ekstrak Inulin Umbi Dahlia

Fruktooligosakarida (FOS) adalah bahan aditif yang sering dimanfaatkan dalam industri makanan, farmasi dan kimia. FOS memiliki nilai fungsional terhadap kesehatan konsumennya. Jenis oligosakarida ini dapat diproduksi dari fraksinasi senyawa polimer inulin dengan bantuan kerja enzim inulinase. Kerja inulinase terbagi menjadi dua aksi pemotongan, yaitu endoinulinase, enzim inulinase memotong rantai inulin di bagian dalam menghasilkan oligosakarida, dan eksoinulinase, enzim inulinase memotong rantai inulin di bagian terminal menghasilkan fraksi-fraksi fruktosa (Yun et al., 1999).

Kluyveromyces marxianus DUCC-Y-003 merupakan jenis khamir inulinolitik karena mampu melakukan aktivitas inulinase secara ekstraseluler terhadap substrat inulin. Aktivitas inulinase khamir ini merupakan sarana dalam mendukung pertumbuhannya. Hasil dari aktivitas inulinase dalam mengkatalisis substrat inulin yaitu berupa beragam oligofruktosa (FOS) serta monomer fruktosa. Dalam penelitian berikut, produksi FOS dilakukan secara mikrobial enzimatis, yaitu produksi FOS dengan memanfaatkan aktivitas enzim yang dihasilkan dari kultur mikroorganisme.

Pengkulturan khamir Kluyveromyces marxianus DUCC-Y-003 pada media perlakuan selama 60 jam telah mampu menghasilkan FOS. Keberadaan FOS dalam media kultur dapat diukur melalui nilai derajat polimerisasi (DP) yang ditentukan dari perbandingan antara kadar total gula dan kadar fruktosa dalam media.

\subsubsection{Analisa Total Gula pada Media Kultur}

Total gula atau yang disebut juga dengan total karbohidrat menurut Apriyantono et al (1986) merupakan jumlah dari keseluruhan gula sederhana, oligosakarida, polisakarida dan turunannya. Analisa untuk menentukan total gula ini dilakukan dengan metode fenol. Bahan sampel harus berupa cairan jernih yang direaksikan dengan fenol dan asam sulfat pekat, sehingga menghasilkan warna coklat kekuningan yang stabil. Oleh karena itu, sampel media kultur harus disentrifugasi terlebih dahulu sehingga mendapatkan supernatan (crude) yang jernih. Analisis total gula dilakukan secara spektroskopi $(\lambda 480 \mathrm{~nm})$ dan dihitung berdasarkan persamaan kurva standar fenol, yaitu :

\section{$Y=-2,1218+0,0003698 X$}

Keterangan :

$\mathrm{Y}=$ nilai absorbansi pada sampel media

$\mathrm{X}=$ kadar total guladalam media $(\mu \mathrm{g} / \mathrm{mL})$. 
Data nilai total gula pada sampel media kultur setiap 6 jam selama 60 jam terdapat pada lampiran 2. Berikut adalah data nilai total gula yang dituangkan dalam grafik :

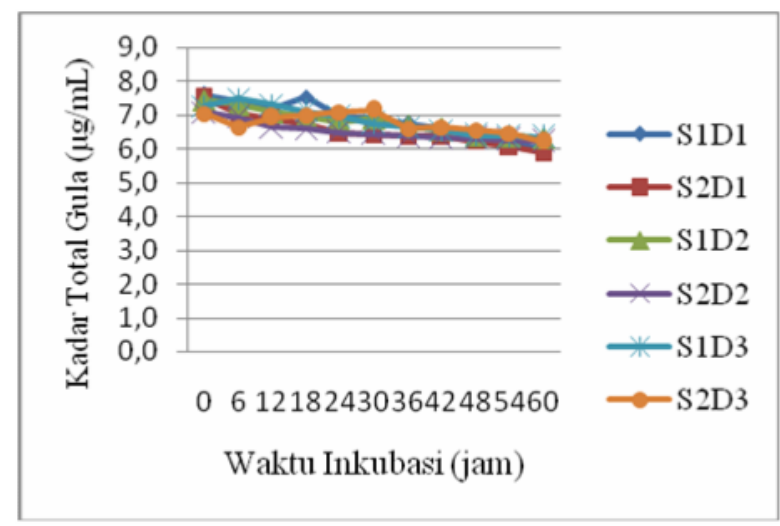

Gambar 2. Grafik nilai total gula pada media perlakuan selama 60 jam.

Berdasarkan grafik di atas, semakin lama waktu inkubasi terjadi penurunan nilai total gula dalam media. Kondisi ini terjadi karena kultur khamir aktif melakukan aktivitas enzimatik dengan memecah polimer inulin yang terkandung dalam substrat menjadi komponen monomermonomer bebas. Semakin lama, rantai polimer inulin menjadi semakin pendek, ditunjukkan dari nilai kadar total gula yang semakin menurun. Polimer panjang inulin telah terpecah menjadi beberapa bagian, yaitu beragam oligomer fruktosa (oligo-fruktosa) dan monomer-monomer fruktosa bebas.

\subsubsection{Analisa Kadar Fruktosa pada Media Kultur}

Fruktosa termasuk dalam golongan gula pereduksi, sebab dalam struktur molekulnya mengandung gugus keton (Goutara dan Widjandi, 1975). Oleh karena itu, analisis kadar fruktosa dilakukan dengan metode DNS secara spektroskopi $\left(\begin{array}{lll}\lambda & 570 & \mathrm{~nm}\end{array}\right)$. Penentuan kadar fruktosa dihitung berdasarkan persamaan kurva standar fruktosa, yaitu :

\section{$\mathrm{Y}=-\mathbf{0 , 0 2 8 8}+\mathbf{0 , 5 3 9 8} \mathrm{X}$}

Keterangan : $\mathrm{Y}=$ nilai absorbansi pada sampel media

$\mathrm{X}=$ kadar fruktosa dalam media $(\mathrm{mg} / \mathrm{mL})$.
Pengukuran kadar fruktosa diperlukan untuk mengetahui banyaknya poli-fruktosa inulin yang telah dikonversi menjadi monomer fruktosa. Data nilai kadar fruktosa pada sampel media kultur setiap 6 jam selama 60 jam terdapat pada lampiran 2. Berikut adalah data kadar fruktosa yang dituangkan dalam grafik :

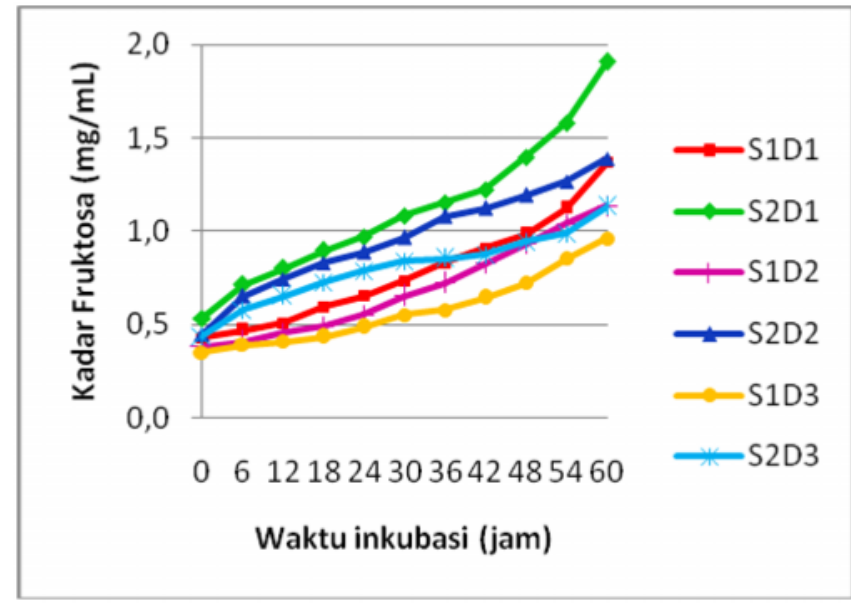

Gambar 3. Grafik kadar fruktosa pada media perlakuan selama 60 jam.

Lama waktu inkubasi media kultur khamir berpengaruh terhadap nilai kadar fruktosa dan total gula dalam media. Semakin lama waktu inkubasi, nilai kadar fruktosa semakin tinggi karena semakin lama suatu bahan dihidrolisis maka pemutusan rantai yang terjadi akan semakin banyak pula, hampir sebagian besar bahan telah dihidrolisis menjadi monomer. Sebaliknya, semakin lama waktu inkubasi, nilai kadar total gula semakin turun, karena banyaknya polisakarida semakin berkurang terpotong-potong menjadi molekul yang lebih sederhana, seperti oligosakarida, disakarida dan monosakarida.

\subsubsection{Pengaruh Total Gula dan Fruktosa Terhadap Derajat Polimerisasi}

Hidrolisis inulin menjadi FOS termasuk dalam proses hidrolisis sebagian (partial hydolysis). Hidrolisis parsial memotong rantai polifruktosa (inulin) secara random sehingga didapatkan sejumlah monosakarida (glukosa dan fruktosa) serta oligosakarida (fruktooligosakarida) (Chaplin dan Kennedy, 1994). 
FOS pada penelitian ini ditentukan dari besarnya nilai derajat polimerisasi (DP). Penentuan nilai DP dipengaruhi oleh kadar total gula dan kadar gula pereduksi (fruktosa). Semakin besar kadar total gula dan semakin kecil kadar fruktosa yang didapat maka nilai DP akan semakin besar, dan sebaliknya. Oleh karena itu, dengan lamanya waktu inkubasi kultur akan didapat nilai DP yang semakin turun. Data hasil perhitungan DP FOS selama 60 jam terdapat pada lampiran 2 . Berikut adalah nilai DP FOS yang dituangkan dalam grafik :

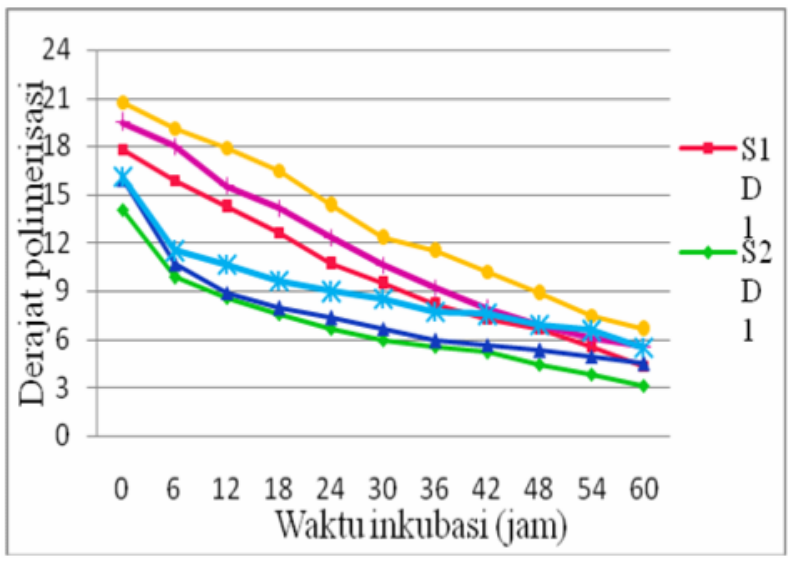

Gambar 4.4. Derajat polimerisasi FOS yang terbentuk selama inkubasi 60 jam pada media perlakuan.

Besar nilai derajat polimerisasi menunjukkan jumlah unit monomer pada makromolekul atau molekul oligomer dalam suatu rantai (IUPAC, 1997). Nilai DP FOS sangat bervariasi. Secara umum, DP FOS berkisar 2-10, karena FOS adalah jenis oligosakarida yang memiliki susunan monomer antara 2-10 unit (Yun et al, 1999). Namun, jenis FOS yang sering dimanfaatkan secara komersil memiliki nilai DP 35. FOS komersil umumnya mengandung campuran dari tiga jenis gula, yaitu 1-kestosa $\left(\mathrm{GF}_{2}\right)$ dengan DP 3, nystosa $\left(\mathrm{GF}_{3}\right)$ dengan DP4, dan fruktofuranosylnystosa $\left(\mathrm{GF}_{4}\right)$ dengan DP 5 . Formula FOS yaitu GFn, G : molekul glukosa, F : molekul fruktosa, dan $\mathrm{n}$ : jumlah fruktosa. Oleh karena itu, nilai DP menentukan formula FOS yang terbentuk (Playne dan Crittenden, 1996; Santos, 2007).
Berdasarkan gambar 4.4, semakin lama waktu inkubasi terjadi penurunan nilai derajat polimerasi. Kondisi ini menunjukkan bahwa terdapat aktivitas inulinase oleh khamir Kluyveromyces marxianus DUCC-Y-003 dalam menghidrolisis inulin menjadi FOS. Secara berkala, khamir melakukan aktivitas inulinase dengan memecah rantai polimer inulin menjadi oligomer-oligomer yang semakin lama semakin pendek. Pemotongan rantai inulin oleh enzim inulinase akan menghasilkan jenis-jenis oligosakarida dengan komposisi molekul fruktosa yang beragam.

Keberadaan FOS dalam media kultur dapat dilihat dari nilai DP yang terbentuk (lampiran 2). Pada perlakuan S1D1, pembentukan FOS mulai terjadi pada waktu 24 jam, S1D2 pada waktu 30 jam dan S1D3 pada waktu 42 jam. Sedangkan, pada perlakuan S2D1 pembentukan FOS terjadi lebih awal yaitu 6 jam, S2D2 dan S2D3 pada waktu 12 jam. Hasil tersebut menunjukkan bahwa media kultur dengan sumber karbon ekstrak inulin (S1) lebih cepat dalam menghasilkan produk FOS, sedangkan pada sumber karbon tepung umbi (S2) membutuhkan waktu yang lebih panjang dalam menghasilkan produk FOS. Hal ini berarti, kultur khamir lebih mudah terinduksi untuk mensintesis enzim inulinase pada media dengan sumber karbon ekstrak inulin. Jumlah dosis sumber karbon juga berpengaruh terhadap aktivitas khamir dalam mensintesis enzim, semakin banyak dosis sumber karbon maka semakin tinggi viskositas media kultur (pekat). Media kultur yang pekat dapat menurunkan agitasi dan aerasinya, sehingga berpengaruh terhadap pertumbuhan kultur khamir. Pertumbuhan khamir yang kurang optimal pada akhirnya dapat berpengaruh terhadap lambatnya produk FOS yang dihasilkan.

Analisis statistik nilai DP FOS dilakukan pada waktu inkubasi 12 jam, 24 jam, 36 jam, 48 jam dan 60 jam. Hasil analisis ragam model Rancangan Acak Kelompok Faktorial (RAKF) memperlihatkan bahwa faktor perlakuan jenis dan dosis sumber karbon berpengaruh nyata terhadap nilai DP FOS yang terbentuk (lampiran 3). Sedangkan, kelompok ulangan tidak berpengaruh terhadap nilai DP FOS. Pengujian lanjut menggunakan uji BNT pada $\alpha=0.05$, yaitu sebagai berikut : 
Tabel 4.1. Hasil uji BNT pengaruh perlakuan terhadap DP FOS pada taraf signifikan 5\%

\begin{tabular}{ccccccc}
\hline \multirow{2}{*}{ Jenis Substrat } & \multirow{2}{*}{ Konsentrasi } & \multicolumn{5}{c}{ Waktu Inkubasi (jam) } \\
\cline { 3 - 7 } & & 12 & 24 & 36 & 48 & 60 \\
\hline S1 & D1 & $14,20^{\mathrm{c}}$ & $10,66^{\mathrm{d}}$ & $8,12^{\mathrm{d}}$ & $6,62^{\mathrm{c}}$ & $4,34^{\mathrm{b}}$ \\
& D2 & $15,55^{\mathrm{d}}$ & $12,33^{\mathrm{e}}$ & $9,20^{\mathrm{e}}$ & $6,89^{\mathrm{d}}$ & $5,57^{\mathrm{d}}$ \\
& D3 & $17,88^{\mathrm{e}}$ & $14,31^{\mathrm{f}}$ & $11,45^{\mathrm{f}}$ & $8,83^{\mathrm{e}}$ & $6,59^{\mathrm{e}}$ \\
\hline S2 & D1 & $8,59^{\mathrm{a}}$ & $6,65^{\mathrm{a}}$ & $5,53^{\mathrm{a}}$ & $4,45^{\mathrm{a}}$ & $3,08^{\mathrm{a}}$ \\
& D2 & $8,91^{\mathrm{a}}$ & $7,32^{\mathrm{b}}$ & $5,90^{\mathrm{b}}$ & $5,29^{\mathrm{b}}$ & $4,47^{\mathrm{c}}$ \\
& D3 & $10,65^{\mathrm{b}}$ & $9,00^{\mathrm{c}}$ & $7,73^{\mathrm{c}}$ & $6,93^{\mathrm{d}}$ & $5,49^{\mathrm{d}}$ \\
\hline
\end{tabular}

Hasil uji BNT untuk nilai DP FOS pada tabel 4.1 menunjukkan bahwa perlakuan terbaik dalam tiap waktu inkubasi terdapat pada perlakuan S2D1 (sumber karbon ekstrak inulin dengan dosis 1 gram). Hal ini berarti, pada waktu inkubasi yang sama namun dengan perlakuan yang berbeda dapat berpengaruh terhadap laju aktivitas enzimatis khamir Kluyveromyces marxianus DUCC-Y-003 dalam menghidrolisis sumber karbon pada media kultur untuk memproduksi FOS. Pada perlakuan sumber karbon tepung umbi, sebenarnya menunjukkan hasil adanya pembentukan FOS dalam media kultur, namun membutuhkan waktu inkubasi yang lebih panjang.

FOS umumnya memiliki nilai DP 2-10, namun FOS yang dimanfaatkan secara komersial memiliki nilai DP 3-5. DP 3 disebut 1-kestosa, DP 4 disebut nystosa, DP 5 disebut fruktofurasylnystosa. Pada masing-masing perlakuan, selama waktu inkubasi 60 jam telah menghasilkan produk FOS dengan nilai DP yang beragam. Akan tetapi, hanya perlakuan S2D1 (ekstrak inulin, 1g) yang sudah menghasilkan ketiga jenis FOS komersil dalam waktu inkubasi 60 jam. Pada perlakuan S2D1, produk 1-kestosa dihasilkan saat inkubasi 42 jam, produk nystosa saat 48 jam dan produk fruktofurasylnystosa saat 60 jam. Oleh karena itu, penggunaan sumber karbon berupa ekstrak inulin dengan dosis 1 gram menunjukkan hasil yang lebih efektif selama waktu inkubasi 60 jam dibanding dengan perlakkuan yang lain.

\section{KESIMPULAN}

Kedua jenis sumber karbon, yaitu tepung umbi dahlia dan ekstrak inulin dari umbi dahlia, mampu berperan sebagai induser terhadap sintesis enzim inulinase oleh khamir Kluyveromyces marxianus DUCC-Y-003, namun ekstrak inulin menunjukkan hasil lebih efektif untuk memproduksi FOS. Sumber karbon ekstrak inulin lebih efektif sebagai substrat untuk memproduksi FOS. Selama waktu inkubasi 60 jam telah mampu menghasilkan produk FOS komersil berupa : $\underline{1-}$ kestosa yang dihasilkan saat inkubasi 42 jam, nystosa saat 48 jam dan fruktofurasylnystosa saat 60 jam. Penambahan dosis sumber karbon tidak selalu sejalan dengan bertambah optimalnya produk FOS yang dihasilkan.

\section{DAFTAR PUSTAKA}

Admin. 2003. Dahlia, Cantik Bunganya dan Manis Umbinya. http://halalmu.or.id/Kunyit CMSHaltek.net. 23 Jun 2003, 11:08:16.

Andyani, N.F. 2001. Produksi Sirup Fruktosa dari Inulin Dahlia Pinnata Cav. secara Hidrolisis Asam. Skripsi, unpublished. Fakultas Teknologi Pertanian, Institut Pertanian Bogor.

British Pharmacopedia. 1980. London Her Majesty’s Stationery Office, London. 
Chaplin, M. F. and J. F. Kennedy. 1994. Carbohydrat Analysis: A Practical Approach. $2^{\text {nd }}$ Edition. Oxford University Press, Oxford.

Fardiaz, S. 1992. Mikrobiologi Pangan. Pusat Antar Universitas Pangan Gizi. Bogor.

Farrar, J.F. \& C.J. Pollock. 1993. The Biology of Fructans. di dalam Kerepesi, I.; M. Tòth; L. Boross. 1996. Water-Soluble Carbohydrates in Dried Plant. J. Agric. Food Chem. 44 : 3235-3239.

Georgescu, L.A. and I. Stoica. 2005. Studies Concerning the Dynamic of Enzyme Hydrolyse on the Jerusalem artichoke (Helianthus tuberosus) Inulin. Journal of Food Technology. 1:77-81.

Gibson, G and F.Angus. 2000. LFRA Ingredients Handbook Prebiotics and Probiotics. Leatherhead Food RA Publishing Limited, Randalls Road, Leatherhead, Surney KT22 7RY.

Gupta, A. K., Kaul, N. and Singh, R. 1992. A Comparison of Properties of Inulinases of Fusarium oxysporum Immobilized on Various Supports. J. Chem. Technol. Biotechnol. 53 : 293-296.

Hanafiah, K. A. 1993. Rancangan Percobaan:Teori dan Aplikasi. Rajawali Press. Jakarta.

Kompas. 2011. Prebiotik Inulin dari Umbi Dahlia. 14 April 2011. 04:13

Kusumawati, I, N. C. Zaini. 2005. Pengaruh Senyawa Prebiotik dari Bawan Merah (Allium cepa) Terhadap Pertumbuahan Bakteri Probiotik. Majalah Farmasi Erlangga, Vol.5 (1):20-24.

Lehninger, Albert L. 1982. Dasar-dasar Biokimia, Jilid 1. Erlangga. Jakarta.

Lisal, J. S. 2005. Konsep Probiotik dan Prebiotik untuk Modulasi Mikrobiota Usus Besar. $J$. Med. Nus. Vol. 26 (4):256-262.

Livingston, D.P. 1990. Fructan Precipitation from Water/Ethanol Extract of Oat and arley. Di dalam Kerepesi, I., Tóth, M. dan Boross, L. 1996. Water-Soluble Carbohydrates in Dried Plant. J. Agric. Food Chem. 44: 3235-3239.

Malcolm, P.S., 2001. Polymer Chemistry : An Introduction, diindonesiakan oleh Lis
Sopyan, cetakan pertama, PT Pradnya

Paramita : Jakarta.

Mangunwidjaja, D., Rahayuningsih, M., Purwoko. 2011. Biokonversi Inulin Umbi Dahlia menjadi Fruktosa dan Fruktooligosakarida. Artikel 101 Inovasi Indonesia 2009. Departemen Teknologi Industri. IPB.

Nakamura, T., Y. Ogata, A.Shitasa, A. Nakamura dan K. Ohta. 1995. Continuous Production of Fructose Syrups from Inulin by Immobilized Inulinase from Aspergillus niger Mutan 817. J. Ferment. and Bioeng. Vol. 80(2):164-169.

Oku, T. and S. Nakamura. 2002. Digestion, Absorption, Fermentation and Metabolism of Functional Sugar Substitutes and Their Available Energy. Pure and Applied Chemistry. Vol 74(7):1253-1261.

Page, D. S. dan R. Soendoro. 1989. Prinsipprinsip Biokimia. Edisi ke-2. Erlangga. Jakarta.

Pessoa, A. and M. Vitolo. 1999. Inulinase from Kluyveromyces marxianus : culture medium composition and enzyme extraction. Braz. J. Chem. Eng. Vol 16. No 3.

Poedjiadi, A. 2006. Dasar-dasar Biokimia. UI Press. Jakarta.

Pool-Zobel BL. 2005. Inulin-type Fructans and reduction in colon cancer risk. Br J Nutr. 93 Suppl 1: S73-90.

Priest, F.G and I. Campbell. 1987. Brewing Microbiology, $2^{\text {nd }}$ Edition. Chapman \& Hall. London.

Rahayuningsih, M. \& R. Purnawati. 1993. Perbaikan Konversi Mikrobial Inulin Menjadi Fruktosa. di dalam Susdiana, Y. 1997. Ekstraksi dan Karakterisasi Inulin dari Umbi Dahlia (Dahlia pinnata Cav). Skripsi, unpublished. Fakultas Teknologi Pertanian, Institut Pertanian Bogor.

Rossi, M, C. Corradini, A. Amaretti, M. Nicolini, A. Pompei, S. Zanoni, D. Matteuzzi. 2005. Fermentation of Fructooligosaccharides and Inulin by Bifidobacteria : a Comparative Study of Pure and Fecal Cultures. J. Appl. Env. Microbiol. 71:6150-6158.

Rouwenhorst, R.J., L.E. Visser, A.A. Van der Baan, W.A. Scheffers \& J.P. Van Dijken. 1988. Production, Distribution, and Kinetic 
Properties of Inulinase in Continuous Cultures of Kluyveromyces marxianus CBS 6556. J. Appl. \& Env. Microbiol. 54 (5): 1131-1137.

Rouwenhorst, R.J., Marco, H., John, V., W. Alexander, S., and J.P. Van Dijken. 1990. Structure and Properties of the Extracellular Inulinase of Kluyveromyces marxianus CBS 6556. Appl \& Env. Microbiol (11):33373345 .

Rukmana, R. 2000. Dahlia : Prospek Agribisnis dan Teknik Budidaya. Kanisius. Yogyakarta.

Sangeetha, P. T, M. N. Ramesha, S. G. Prapullaa. 2005. Recent Trend in the Microbial Production, Analysis and Applications of Fructooligosaccharides. Trend in Food Science \& Technology. Vol 16 : 442-457.

Santos, A. M. P and F. Maugeri. 2007. Synthesis of Fructooligosaccharides from Sucrose Using Inulinase from Kluyveromyces marxianus. J. Food Technol and Biotechnol. Vol 45 (2):181-189.

Saptono, R. 2008. Kimia Polimer. Departemen Metalurgi dan Material FTUI. Jakarta.

Saryono, P. Sulistyati., D. Zul, dan A. Martina. 1997. Identifikasi Jamur Pendegradasi Inulin pada Rizosfer Umbi Dahlia (Dahlia variabilis). Jurnal Natur Indonesia 11 (1): 22-27.

Saryono, A. Martina, dan A.M. Chainulfifah. 2002. Isolasi dan Karakterisasi Jamur Penghasil Inulinase yang Tumbuh pada Umbi Dahlia. Jurnal Natur Indonesia 4 (2): 171-177.

Saryono. 2008. Isolasi dan Karakteristik Inulinase dari Aspergillus niger Gmn11.1 Galur Lokal. Jurnal Natur Indonesia 11 (1): 19-23.

Singh, P. Gill, K. Prabhjot. 2006. Production of Inulinase : Recent Advances. Food Technol. Biotechnol 44 (2) : 151-162.

Singh, R.S.; Sooch, B.S.; Puri M. 2007.Optimization of medium and process parameters for the production of inulinase from a newly isolated Kluyveromyces marxianus YS-1. Biores. Technol. 98 : 25182525 .

Sudarmadji, S. Bambang H. dan Suhardi. 1984. Analisa Bahan Makanan dan Pertanian. Edisi ke-3. Penerbit Liberty bekerjasama dengan PAU Pangan dan Gizi UGM. Yogyakarta.

Susdiana, Y. 1997. Ekstraksi dan Karakterisasi Inulin dari Umbi Dahlia (Dahlia pinnata Cav). Skripsi, unpublished. Fakultas Teknologi Pertanian, Institut Pertanian Bogor.

Vandamme, E. J. and D.G. Derycke. 1983. Microbial Inulinase: Fermentation Process, Properties and Applications. Advance in Appl. Micro 29: 139-176.

Waluyo, L. 2004. Mikrobiologi Umum. Universitas Muhammadiyah Press. Malang.

Wang, X. and G. R. Gibson. 1993. Effect of in vitro Fermentation of Oligofructose and Inulin by Bacteria Growing in the Human Large Intestine. J. Appl. Bact. 75:373-380.

Wardhanu, A. P. 2009. Kharakteristik dan Morfologi Yeast. http://apwardhanu.wordpress.com/. $\quad 15$ Januari 2009, 10:56.

Widowati, S., Titi, C.S., Zahrani. 2005. Ekstraksi, Karakterisasi, dan Kajian Potensi Prebiotik Inulin dari Umbi Dahlia (Dahlia pinnata L.). Jurnal IPB, Bogor.

Widowati, S. 2009. Tepung Aneka Umbi : Sebuah Solusi Ketahanan Pangan. Sinar Tani Edisi 6-12, No.3302 Tahun XXXIX. Balai Besar Penelitian dan Pengembangan Pascapanen Pertanian. Bogor.

Wijanarka, Sutariningsih, E., Dewi, K., Indrianto, A. 20011. Isolasi Yeast Inulinolitik dan Optimasi Produksi Inulinase pada Berbagai Konsentrasi Nitrogen Yeast Ekstrak Sebagai Sumber N. BIOMA 13 (1).

Xiao, R., Masatoshi, T. and Shoici, T. 1988 Inulinase from Crysosorium pannorum. J. Ferment and Tech 66 (5) : 244-248.

Yun, J. W, C. H. Song, J. W. Choi, S. K. Song. 1999. Microbial Production of Inulooligosaccharides by an Endoinulinase from Pseudomonas sp. Expressed in Escherichia coli. J. Biosci. Bioeng. 87 : 291-295.

Zherebtsov, N.A., S.A Shelamova and I.N Abramova. 2002. Biosinthesis of Inulinases by Bacillus Bacteria. Appl. Biochem and Microbiol Vol.38 (6): 544-548. 
BIOMA, Juni 2014

ISSN: $1410-8801$

Vol. 16, No. 1, Hal. 39-49 